\title{
Is Halophila major (Zoll.) Miquel a big H. ovalis (R. Brown) J.D. Hooker? An evaluation based on age, morphology, and ITS sequence
}

\author{
Piyalap Tuntiprapas ${ }^{\mathrm{a}}$, Satoshi Shimada ${ }^{\mathrm{b}}$, Supattra Pongparadon ${ }^{\mathrm{c}}$, Anchana Prathep ${ }^{\mathrm{c}, *}$ \\ a Excellence Centre for Biodiversity of Peninsular Thailand, Faculty of Science, \\ Prince of Songkla University, Thailand \\ b Graduate School of the Natural/Applied Sciences, Division Ochanomizu University, Tokyo \\ c Seaweed and Seagrass Research Unit, Department of Biology, Faculty of Science, \\ Prince of Songkla University, HatYai, Songkhla 90112 Thailand
}

*Corresponding author, e-mail: anchana.p@psu.ac.th

Received 26 Dec 2014

Accepted 1 Mar 2015

\begin{abstract}
The common seagrass, Halophila ovalis (R. Brown) J.D. Hooker, is highly variable morphologically. It adapts well to various environmental conditions rendering the various forms unclear taxonomically. Halophila species were collected along the coast of southern Thailand. The morphology was quantified according to different parts of the leaf and the ages of leaves. Some samples had significantly different characters from $H$. ovalis: the lengths of their leaves ranged from 11.7-29.4 mm, and the widths from 5.6-14.8 mm; there were 9-18 cross veins. Phylogenetic analyses based on ribosomal internal transcribed spacer sequences divided them into two groups: one agrees with $H$. ovalis and the other with $H$. major. We suggest that leaf size at maturity (age iii-iv) and the $1 / 2$ ratio between the leaf width and the space between the intra-marginal vein and lamina margin are important characters that distinguish Halophila species.
\end{abstract}

KEYWORDS: seagrass, nrITS, leaf age, Thailand

\section{INTRODUCTION}

The genus Halophila Thouars (1806), family Hydrocharitaceae (Alismatales, Monocots) ${ }^{1}$ has a broad global distribution ${ }^{2}$, and is one of the most important marine plant due to its ecological roles as primary producer in marine environments ${ }^{3}$. Halophila ovalis (R. Brown) J.D. Hooker is the most common species in this genus found in the IndoPacific, the temperate North Pacific, the temperate Southern Oceans, and has recently been observed in the Tropical Atlantic Ocean ${ }^{4}$. It is well known for its variable morphology and adaptability to various environmental conditions ${ }^{5-8}$. Although $H$. ovalis is widely distributed, it has been represented as a single collective species ${ }^{1,9}$.

The five species of Halophila reported from Thailand are $H$. ovalis, $H$. beccarii, $H$. minor, $H$. decipiens, and H. major ${ }^{10-12}$. H. ovalis is also common in Thai waters, forming extensive beds along the Andaman coast. It is well documented as food for the dugong, an endangered marine mammal ${ }^{11,13,14}$. Seagrass studies in Thailand are however scant ${ }^{15,16}$ and taxonomic studies have not been revised in the last 10 years. For example, only $H$. decipiens, $H$. ovalis, and $H$. ovata have been reported in the Flora of Thailand ${ }^{17}$, where $H$. ovata was placed as a synonym of $H$. minor. Later however it was recognized as two distinct species ${ }^{18}$. H. ovata is now an illegitimate name and is proposed as $\mathrm{H}$. gaudichaudii ${ }^{19}$; but a recent study ${ }^{12}$ suggested that $H$. gaudichaudii was a synonym of $H$. nipponica. These observations reveal that the taxonomic status of the group is still unclear. Besides, molecular studies by Uchimura et $\mathrm{al}^{12}$ revealed that $H$. major occurred in Thailand, which was the first record of H. major in Thailand. A recent report by Nguyen et $\mathrm{al}^{20}$ suggested the occurrence of $\mathrm{H}$. major in Thailand; however its morphological features had never been examined.

During our recent surveys, we have found many Halophila specimens in several locations with similar characters to $H$. ovalis, but some with greater leaf size and thick leaf. Both forms grow in the subtidal zones also mixed with Thalassia hemprichii and Cymodocea serrulata. Recent studies using var- 


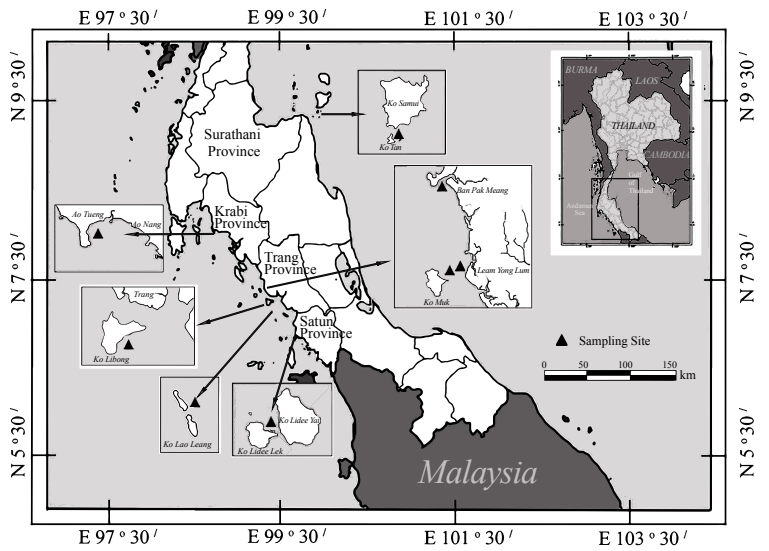

Fig. 1 Field collection sites along the coastal southern Thailand.

ious genetic markers of plastid sequences have clarified the identification of the Halophila species ${ }^{21,22}$. Ribosomal internal transcribed spacer (ITS) sequences could be used to study and identify the genetic relation between Halophila closely related species ${ }^{12,20,23,24}$. It is unknown weather there is any difference in ITS molecular analysis between big and small leaf morphological forms of $H$. ovalis. Thus this study evaluates the taxonomic status of this large Halophila sp. by analysing the nuclear ribosomal internal transcribed spacer (nrITS) sequences and measuring different leaf parts at various ages.

\section{MATERIALS AND METHODS}

Seagrasses were collected from the intertidal and subtidal zones along the coastal line in southern Thailand (Fig. 1). Samples were collected by walking survey during low tide at intertidal zone area and by using SCUBA diving or snorkelling at the subtidal area. At each sampling point plants containing leaf, root, and rhizome having at least 3-4 leaf pairs were selected, cleaned, and preserved as dried herbarium specimens. New and/or young leaves of Halophila with no epiphytes were preserved in silica gel for molecular studies. These vouchers herbarium specimens were deposited at Princess Maha Chakri Sirindhorn Natural History Museum, Prince of Songkla University, Hat Yai.

Total DNA was extracted from 38 samples (Table 1) using the DNeasy Plant Mini Kit (QIAGEN, Valencia, CA, USA) following the protocol of the manufacturer. The nuclear ribosomal internal transcribed spacer (nrITS) region including the $5.8 \mathrm{~S}$ gene was selected for PCR amplification and auto- mated sequencing. The following pair of primers was used for PCR and cycle-sequencing reactions: ITS1 ( $5^{\prime}$-TCCGTAGGTGAACCTGCGG - $3^{\prime}$ ) and ITS4 ( $5^{\prime}$-TCCTCCGCTTATTGATATGC- ${ }^{\prime}$ ). PCR amplification was run on a PROGRAM TEMP CONTROL SYSTEM (Astec, Fukuoka, Japan) and the profile of the reactions was an initial denaturation $1 \mathrm{~min}$ at $94^{\circ} \mathrm{C}$ followed by 35 cycles of denaturation $45 \mathrm{~s}$ at $94^{\circ} \mathrm{C}$, the primers annealing $45 \mathrm{~s}$ at $50^{\circ} \mathrm{C}$, and extension $60 \mathrm{~s}$ at $72^{\circ} \mathrm{C}$, terminated by a final hold at $4{ }^{\circ} \mathrm{C}$. The presence of the PCR-amplified products was verified by agarose gel electrophoresis, followed by staining with ethidium bromide. Prior to cyclesequencing, PCR-amplified products were cleaned using the QIAquick PCR Purification Kit (QIAGEN, Valencia, CA, USA) and directly sequenced using the ABI PRISM BigDye Terminator Cycle Sequencing Kit ver. 3.1 (Applied Biosystems, CA, USA) according to the manufacturers. Cycle-sequencing reactions consisted of an initial step of $96^{\circ} \mathrm{C}$ for $10 \mathrm{~s}$, followed by 25 cycles $\left(96^{\circ} \mathrm{C}\right.$ for $10 \mathrm{~s}, 50^{\circ} \mathrm{C}$ for $5 \mathrm{~s}, 60^{\circ} \mathrm{C}$ for $4 \mathrm{~min}$ ) and a final hold at $4^{\circ} \mathrm{C}$. Only the forward strand was sequenced using a DNA autosequencer (ABI PRISM, 3130 Genetic Analyser, Applied Biosystems, CA, USA).

The sequences were aligned using CLUSTAL $\mathrm{X}^{25}$. Identical sequences within each species were excluded from the alignment. Additional 29 ingroup sequences were loaded from GenBank (Table 1). H. decipiens Ostenfeld (AF366412) and H. stipulacea (Forssk.) Asch. (AF366436) designated as outgroups. Phylogenetic analysis were implemented using maximum likelihood (ML) and Bayesian Inference (BI). Prior to ML and BI analysis, the best-fit model of nucleotide substitution was selected using the JMODELTEST 2.1.1 tool ${ }^{26}$. The ML tree was constructed using RAXML ${ }^{27}$ with the $\mathrm{HKY}+\mathrm{I}+\mathrm{G}$ model. Support for branches was obtained from 1000 bootstrap replications. BI analysis was performed using MRBAYES v.3.2.1 ${ }^{28}$, with a random starting tree run for 5000000 generations, sampling tree every 1000 generations and a with a burning of 5000 trees.

The herbarium specimens were closely examined under a stereo microscope (Olympus SZX 12) and photographed using an Olympus DP 71. Each leaf was divided into 4 equal sections from the base to the apex (Fig. 2). The leaf morphological characters were quantified as follows: leaf length (LL) and leaf width (LW) in each of the four sections, number of cross veins (CV), counted from the base of all cross vein (secondary vein) which are connected with the mid rib (primary vein), cross 
Table 1 Samples collected from southern Thailand and sequence data that use in this study.

\begin{tabular}{|c|c|c|c|c|c|}
\hline No. & Taxon & Location & Voucher No. & GenBank No. & Source \\
\hline 1 & H. ovalis & Okinawa, Japan & & AB243973 & 23 \\
\hline 2 & H. ovalis & Okinawa, Japan & & $\mathrm{AB} 243975$ & 23 \\
\hline$\overline{3}$ & H. ovalis & Trang, Thailand & & AB436938 & 12 \\
\hline 4 & H. ovalis & Trang, Thailand & & AB436939 & 12 \\
\hline 5 & H. ovalis & Queensland, Australia & & AF366431 & 29 \\
\hline 6 & H. ovalis & Marakanam, India & & KF620355 & 20 \\
\hline 7 & H. ovalis & Kanyakumari, India & & KF620353 & 20 \\
\hline 8 & H. ovalis & Trang, Thailand & & KF620350 & 20 \\
\hline 9 & H. ovalis & Nakhon Si Thammarat, Thailand & & KF620345 & 20 \\
\hline 10 & H. ovalis & Satun, Thailand & & KF620347 & 20 \\
\hline 11 & H. ovalis & Lantau Island, Hong Kong & & KF620337 & 20 \\
\hline 12 & H. ovalis & $\mathrm{Cu}$ Mong Lagoon, Vietnam & & KC175909 & 20 \\
\hline 13 & H. ovalis & Sarawak, Malaysia & & KF620338 & 20 \\
\hline 14 & H. ovalis & Tiga Island, Malaysia & & KF620339 & 20 \\
\hline 15 & H. ovalis & Johore, Malaysia & & KF620346 & 20 \\
\hline 16 & H. ovalis & Flores Island, Indonesia & & $\mathrm{AB} 436930$ & 12 \\
\hline 17 & H. ovalis & Leam Yong Lum, Trang, Thailand & PT $45.1 .1^{*}$ & KP408228 & $\dagger$ (Group Ho.1) \\
\hline 18 & H. ovalis & Leam Yong Lum, Trang, Thailand & PT 45.2.1 & KP408229 & $\dagger$ (Group Ho. 1) \\
\hline 19 & H. ovalis & Leam Yong Lum, Trang, Thailand & PT 49.1.1* & KP408230 & $\dagger$ (Group Ho. 1) \\
\hline 20 & H. ovalis & Leam Yong Lum, Trang, Thailand & PT 49.2 .2 & KP408231 & $\dagger$ (Group Ho. 1) \\
\hline 21 & H. ovalis & Leam Yong Lum, Trang, Thailand & PT 49.3 .4 & KP408232 & $\dagger$ (Group Ho.1) \\
\hline 22 & H. ovalis & Leam Yong Lum, Trang, Thailand & PT 52.1 .2 & KP408233 & (Group Ho. 1) \\
\hline 23 & H. ovalis & Leam Yong Lum, Trang, Thailand & CK $13-1$ & KP408234 & $\dagger$ (Group Ho. 1) \\
\hline 24 & H. ovalis & Leam Yong Lum, Trang, Thailand & CK $14-2$ & KP408235 & $\dagger$ (Group Ho. 1) \\
\hline 25 & H. ovalis & Leam Yong Lum, Trang, Thailand & CK $14-6$ & KP408236 & $\dagger$ (Group Ho. 1) \\
\hline 26 & H. ovalis & Leam Yong Lum, Trang, Thailand & CK 14-7 & KP408237 & $\dagger$ (Group Ho.1) \\
\hline 27 & H. ovalis & Leam Yong Lum, Trang, Thailand & CK $15-5$ & KP408238 & $\dagger$ (Group Ho. 1) \\
\hline 28 & H. ovalis & Leam Yong Lum, Trang, Thailand & CK $15-7$ & KP408239 & $\dagger($ Group Ho. 1) \\
\hline 29 & H. ovalis & Leam Yong Lum, Trang, Thailand & CK $19-5$ & KP408240 & $\dagger$ (Group Ho. 1) \\
\hline 30 & H. ovalis & Koh Tan, Suratthani, Thailand & CK 24-1 & KP408241 & $\dagger$ (Group Ho.1) \\
\hline 31 & H. ovalis & Koh Tan, Suratthani, Thailand & CK 24-2 & KP408242 & $\dagger$ (Group Ho. 1) \\
\hline 32 & H. ovalis & Koh Tan, Suratthani, Thailand & CK 24-3 & KP408243 & (Group Ho. 1) \\
\hline 33 & H. ovalis & Koh Tan, Suratthani, Thailand & CK 24-3.4 & KP408244 & $\dagger$ (Group Ho. 1) \\
\hline 34 & H. ovalis & Koh Tan, Suratthani, Thailand & CK $24-4$ & KP408245 & $\dagger$ (Group Ho.1) \\
\hline 35 & H. ovalis & Koh Tan, Suratthani, Thailand & CK 24-5 & KР408246 & $\dagger$ (Group Ho. 1) \\
\hline 36 & H. ovalis & Ban Pak Meang, Trang, Thailand & PT 46.1 .2 & KP408247 & $\dagger$ (Group Ho. 1) \\
\hline 37 & H. ovalis & Ban Pak Meang, Trang, Thailand & PT 46.1 .3 & KP408248 & (Group Ho. 1) \\
\hline 38 & H. ovalis & Ban Pak Meang, Trang, Thailand & PT 46.2 .4 & KP408249 & $\dagger$ (Group Ho. 1) \\
\hline 39 & H. ovalis & Ban Pak Meang, Trang, Thailand & PT 46.3 .1 & KP408250 & $\dagger$ (Group Ho.1) \\
\hline 40 & H. ovalis & Ban Pak Meang, Trang, Thailand & PT 47.2 .2 & KP408251 & $\dagger$ (Group Ho. 1) \\
\hline 41 & H. ovalis & Ban Pak Meang, Trang, Thailand & PT 47.1 .3 & KP408252 & $\dagger$ (Group Ho. 1) \\
\hline 42 & H. ovalis & Ban Pak Meang, Trang, Thailand & PT 62.1 & KP408253 & $\dagger$ (Group Ho.1) \\
\hline 43 & H. ovalis & Koh Lidee, Satun, Thailand & PT 57.1.1 & KP408254 & $\dagger$ (Group Ho.1) \\
\hline 44 & H. ovalis & Leam Yong Lum, Trang, Thailand & PT $49.1 .5^{*}$ & KP408255 & $\dagger$ (Group Ho.2) \\
\hline 45 & H. major & Trang, Thailand & & AB436927 & 12 \\
\hline 46 & H. major & Okinawa, Japan & & $\mathrm{AB} 243967$ & 23 \\
\hline 47 & H. major & Sumbawa, Indonesia & & $\mathrm{AB} 436926$ & 12 \\
\hline 48 & H. major & Bali, Indonesia & & AB436928 & 12 \\
\hline 49 & H. major & Nha Trang, Vietnam & & KC175910 & 20 \\
\hline 50 & H. major & Gyeiktan, Myanmar & & KF620352 & 20 \\
\hline 51 & H. major & Mabul Island, Malaysia & & KF620340 & 20 \\
\hline 52 & H. major & Leam Yong Lum, Trang, Thailand & PT $48.1 .1^{*}$ & KP408256 & ${ }^{\dagger}$ (Group Hm.2) \\
\hline 53 & H. major & Leam Yong Lum, Trang, Thailand & PT $48.1 .2^{*}$ & KP408257 & $\dagger($ Group Hm.3) \\
\hline 54 & H. major & Leam Yong Lum, Trang, Thailand & PT 48.2.3 & KP408258 & (Group Hm. 1) \\
\hline 55 & H. major & Leam Yong Lum, Trang, Thailand & PT 48.3.1* & KP408259 & † (Group Hm. 1) \\
\hline 56 & H. major & Leam Yong Lum, Trang, Thailand & PT $51.1 .2^{*}$ & KP408260 & † (Group Hm. 1) \\
\hline 57 & H. major & Koh Libong, Trang, Thailand & PT 133.10 & KP408261 & $\dagger($ Group Hm. 1) \\
\hline 58 & H. major & Koh Muk, Trang, Thailand & CK $16-3$ & KP408262 & $\dagger($ Group Hm. 1) \\
\hline 59 & H. major & Ko Lao Liang, Trang, Thailand & SP 348 & KP408263 & (Group Hm. 1) \\
\hline 60 & H. major & Ao Nang, Krabi, Thailand & AD $178 \mathrm{a}$ & KP408264 & $\dagger($ Group Hm. 1) \\
\hline 61 & H. major & Ao Nang, Krabi, Thailand & AD $178 \mathrm{~b}$ & KP408265 & $\dagger($ Group Hm. 1) \\
\hline 62 & H. australis & South-Western Australia & & AF366414 & 29 \\
\hline 63 & H. hawaiiana & Hawaii, USA & & AF366426 & 29 \\
\hline 64 & H. johnsonii & Florida, USA & & AF366425 & 29 \\
\hline 65 & H. mikii & Kagoshima Pref., Japan & & AB436929 & 12 \\
\hline 66 & H. minor & Guam & & AF366405 & 29 \\
\hline 67 & H. minor & Philippines & & AF366406 & 29 \\
\hline 68 & H. stipulacea & Sicily, Italy & & AF366436 & 29 \\
\hline 69 & H. decipiens & Malaysia & & AF366412 & 29 \\
\hline
\end{tabular}

" measurement samples in this study

$\dagger$ this study 


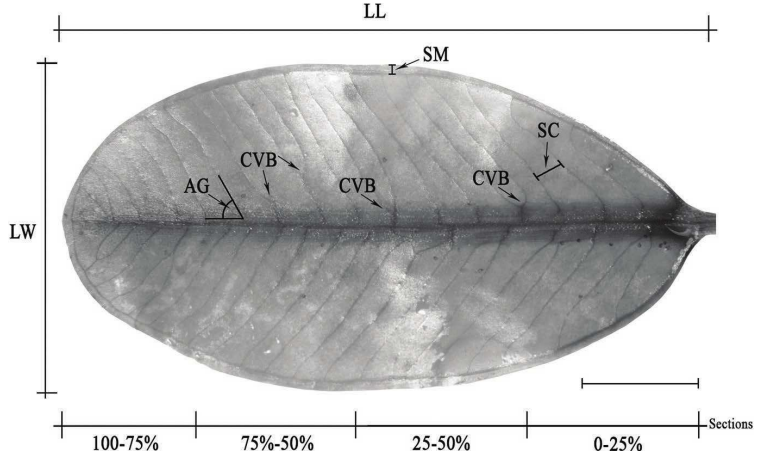

Fig. 2 Leaf characters of Halophila major that were measured in each section. LL: leaf length; LW: leaf width; AG: angle between cross veins and mid veins; CVB: cross veins branching; SC: space between cross veins; SM: distance between intramarginal veins and lamina margin. Scale bar is $5 \mathrm{~mm}$.

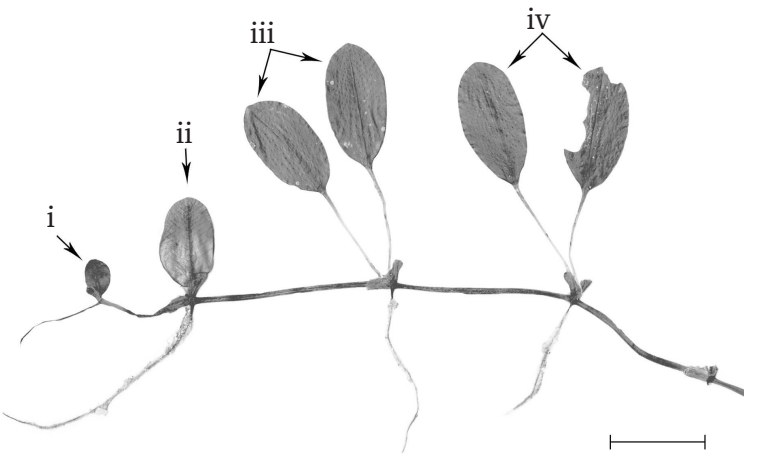

Fig. 3 Leaf age classes. (i) Young or new leaf without the petiole; (ii) young leaf nearly mature and shot petiole length (2nd of leaf pairs); (iii) fully youngest mature (3rd leaf pairs); (iv) old leaf (4th-5th leaf pairs). Scale bar is $3 \mathrm{~cm}$.

vein branching counted from the base of cross vein which branched in the end of cross vein. The space between cross veins (SC) and the space between the intra-marginal vein and the lamina margin (SM) measured as the distance between each characters. The angle of cross veins ascending measured at the angle between the mid vein and the cross vein in each section. All these character parameters were examined using an image analysis program (image J software version 1.46r). Three replicates of each character parameters were made. The leaves were also divided into 4 age classes (Fig. 3): Age (i) is the young or new apical leaf with petiole development, age (ii) is young leaf nearly mature and with a short petiole (2nd leaf pairs), age (iii) is fully young mature (3rd leaf pairs), and age (iv) is an old leaf (4th leaf pairs). Leaves at each age were divided into the 4 sections and examined as above. The homoscedasticity of data was tested using Levene's test; and Two-ways ANOVA was employed to compare the difference in those characters with respect to species at each age; and Welch ANOVA was employed if data are heteroscedasticity.

\section{RESULTS}

\section{Molecular phylogeny and ecological aspects}

The phylogenetic tree obtained with the Ml method is presented in Fig. 4. Both maximum likelihood (Ml) and Bayesian Inference trees have the same topology. Thirty eight ITS sequences were divided into two clades consisting of clade I and clade II with 99 bootstrap percentages and 1 of Bayesian Inference posterior probabilities. In clade I, both haplotype Ho. 1 and Ho. 2 were grouped with known sequences, $H$. ovalis from GenBank. The 27 samples (Ho.1) were identical but different by 2 bp from H. ovalis AB243973 (JP). The haplotype Ho.2 was identical with $H$. ovalis sequences KF620345(TH), KF620347(TH), AB436938(TH), KF620337(HK), KF620338(ML2) and KF620339(ML3) but different by 2 bp from haplotype Ho.1. In clade II, haplotype Hm.1, Hm.2 and Hm.3 were clustered with known sequences, $H$. major from GenBank. Haplotype Hm.1 (8 samples) were identical with H. major AB436927(TH). Haplotype Hm.2 and Hm. 3 were grouped with AB436928 and AB436926 from Indonesia, respectively. Hm.1 differed by 5 bp from Hm.2 and 6 bp from Hm.3, while Hm.2 and Hm.3 differed only $1 \mathrm{bp}$. The results showed the nucleotide differences among individuals of $H$. ovalis clade and $H$. major clade were $0-15$ nucleotides and 0-14 nucleotides, respectively. Intraspecies variations were $0-0.014 \%$ ( $H$. major), $0-$ $0.015 \%$ (H. ovalis) and $0-0.018 \%$ (H. nipponica). Inter-species variations between $H$. major/H. ovalis, $H$. major/H. nipponica or $H$. ovalis/H. nipponica were $0.04-0.057 \%, 0.05-0.068 \%$ or $0.031-0.047 \%$, respectively.

H. ovalis has occurred in both Andaman Sea and Gulf of Thailand while $H$. major was found only in the Andaman Sea. H. ovalis and H. major from In Leam Yong Lum, Trang province showed great genetic variations, covered both haplotypes of H. ovalis (Ho.1 and Ho.2) and all of H. major (Hm.1, Hm.2, and Hm.3).

\section{Morphological observations}

The molecular analysis revealed that the largeleafed Halophila species is H. major (Zoll.) Miq. 


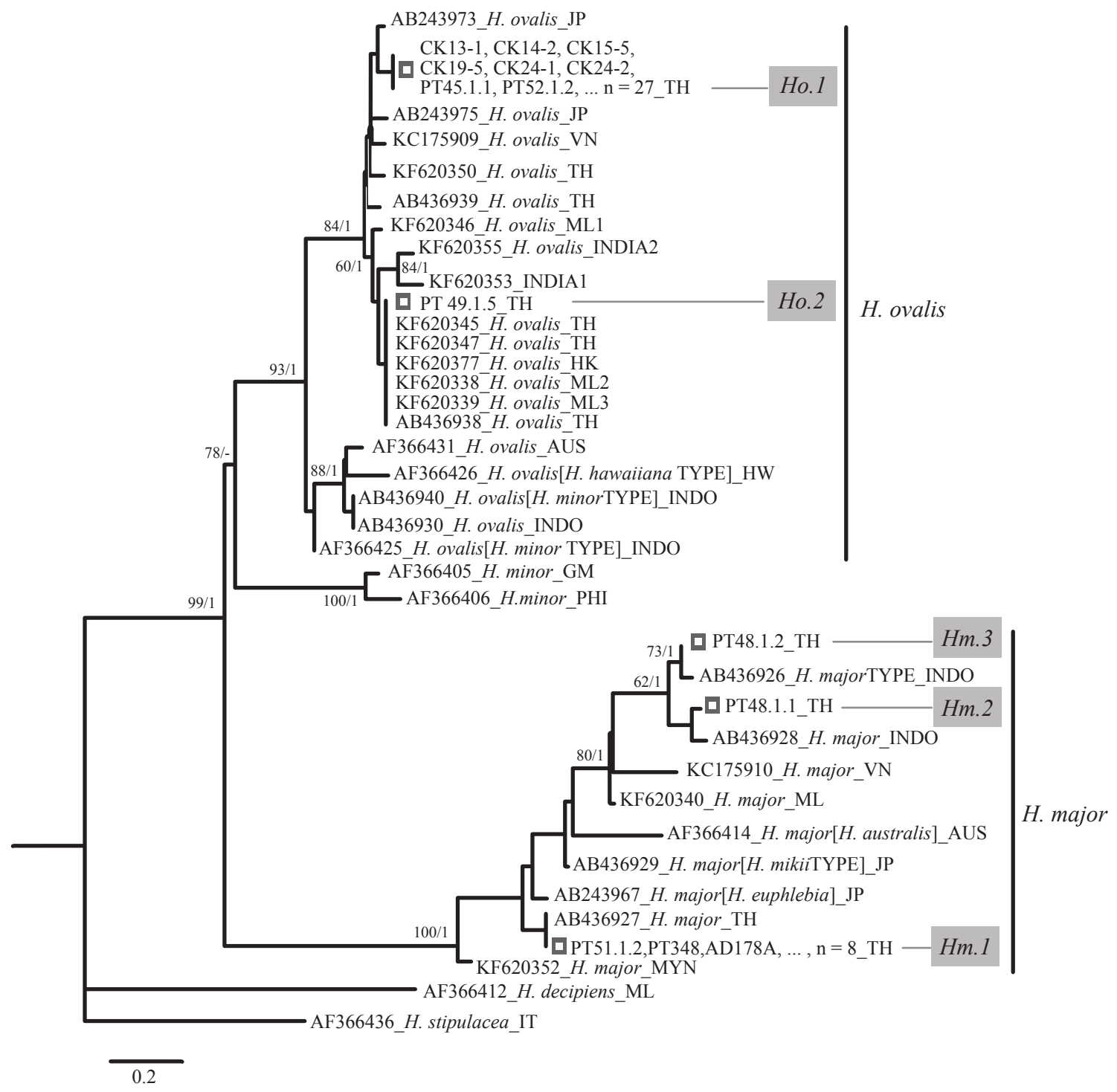

Fig. 4 ML tree of Halophila species (nrITS: 635 bp). ML bootstrap values ( $>50)$ and BI posterior probabilities ( $>0.80$ ) are indicated at nodes.

A total of 20 morphological leaf characters in 4 age classes were examined and compared between $H$. major and $H$. ovalis. The leaf characters showed the variation between the species among age classes (Table 2). Out of the 20 examined characters, there were 9 morphological leaf characters that featured significant differences between species in each age; which were leaf length, leaf width in each section, number of cross veins, space between cross veins (SC) in each section (except at $25 \%$ leaf area), space between the intra-marginal vein and lamina margin (SM) at the leaf tip and ratio between $1 / 2$ leaf width and the space between the intra-marginal vein and lamina margin (Fig. 5a-i). The differences in leaf character between $H$. major and $H$. ovalis were closely observed as also summarized in Table 2. Leaf length and width ranged 23.9-29.4 mm and 10.8$12.6 \mathrm{~mm}$ in $\mathrm{H}$. major and $10-17 \mathrm{~mm}$ and $4.3-$ $836 \mathrm{~mm}$ in $\mathrm{H}$. ovalis, respectively, (Fig. 5a-d). The numbers of cross veins were $14-18$ veins in $H$. major and were 9-16 veins in $H$. ovalis (Fig. 5e). Space between cross veins at 50\%, $75 \%$ and $100 \%$ leaf area were slightly increased in space with aged. However, $H$. major had wider space between cross veins than $H$. ovalis (Fig. $5 \mathrm{f}-\mathrm{h}$ ). Interestingly, the ratio between $1 / 2$ leaf width and the space between the intra-marginal vein and lamina margin was clearly different. A much greater ratio was found 
Table 2 Summary of morphological characters between $H$. major and H. ovalis populations.

\begin{tabular}{|c|c|c|c|c|c|c|c|c|c|}
\hline Characters $^{\dagger}$ & $\begin{array}{c}\mathrm{LL} \\
(\mathrm{mm})\end{array}$ & $\begin{array}{c}\mathrm{LW} \\
(\mathrm{mm})\end{array}$ & $\begin{array}{c}\text { CV } \\
\text { (no.) }\end{array}$ & $\begin{array}{l}\text { CVB }^{*} \\
\text { (no.) }\end{array}$ & $\begin{array}{c}\text { SC } \\
(\mathrm{mm})\end{array}$ & $\begin{array}{c}\mathrm{SM} \\
(\mathrm{mm})\end{array}$ & $\begin{array}{l}\text { SMa } \\
(\mathrm{mm})\end{array}$ & $\begin{array}{l}\text { AG } \\
\left({ }^{\circ}\right)\end{array}$ & $1 / 2 \mathrm{LW} / \mathrm{SM}$ \\
\hline \multicolumn{10}{|l|}{ H. ovalis (n) } \\
\hline age (i) (8) & $6.8-10.1$ & $4.6-5.6$ & $7-8$ & $(2-3)$ & $\mathrm{n} / \mathrm{d}^{\#}$ & $0.1-0.4$ & $0.37-0.39$ & $59.3-77.3$ & $1: 8-9.2$ \\
\hline age $^{*}$ (ii) (7) & $12.7-18.2$ & $6.1-8.2$ & $11-14$ & $(1-4)$ & $0.4-1.3$ & $0.2-1.2$ & $0.3-0.5$ & $36.3-89.4$ & $1: 3.6-12.7$ \\
\hline age (iii) (11) & $11.2-17.0$ & $4.3-8.3$ & $9-16$ & $(0-3)$ & $0.4-1.4$ & $0.2-1.1$ & $0.3-0.5$ & $30.4-88.5$ & $1: 4.1-9.7$ \\
\hline age (iv) (12) & $10.0-15.0$ & $4.6-7.6$ & $9-14$ & $(0-3)$ & $0.3-1.1$ & $0.2-0.6$ & $0.3-0.5$ & $43.4-79.4$ & $1: 6.8-12.1$ \\
\hline Japan $^{19}$ & $12-18$ & 4-8 & $12-16$ & $\mathrm{n} / \mathrm{d}$ & $0.8-1.1$ & $0.25-0.4$ & $\mathrm{n} / \mathrm{d}$ & $\mathrm{n} / \mathrm{d}$ & 1:10-16 \\
\hline Vietnam $^{24}$ & $9-12$ & $3.7-7.0$ & $8-16$ & $\mathrm{n} / \mathrm{d}$ & $\mathrm{n} / \mathrm{d}$ & 0.3 & $\mathrm{n} / \mathrm{d}$ & $45-80$ & 1:9-17 \\
\hline \multicolumn{10}{|l|}{ H. major (n) } \\
\hline age (i) (9) & $11.7-19.5$ & $7.1-12.6$ & $9-16$ & $(0-5)$ & $0.5-1.5$ & $0.1-0.5$ & $0.2-0.5$ & $36.5-87.4$ & $1: 16.6-22.2$ \\
\hline age (ii) (5) & $13.0-25.7$ & $5.6-14.8$ & $12-18$ & $(1-6)$ & $0.5-1.5$ & $0.1-1.5$ & $0.2-0.5$ & $30.1-77.7$ & $1: 18.5-19.9$ \\
\hline age (iii) (15) & $25.9-29.4$ & $10.8-12.6$ & $14-18$ & $(1-6)$ & $0.6-2.0$ & $0.1-0.6$ & $0.4-0.6$ & $27.7-75.4$ & $1: 16.6-27.1$ \\
\hline age (iv) (8) & $23.9-27.4$ & $10.8-12.3$ & $15-18$ & $(1-6)$ & $0.6-1.5$ & $0.2-0.6$ & $0.4-0.6$ & $36.9-67.3$ & $1: 17.2-27.7$ \\
\hline Japan $^{19}$ & $10-25$ & 9-11 & $18-22$ & $\mathrm{n} / \mathrm{d}$ & $0.7-1.25$ & $0.16-0.5$ & $\mathrm{n} / \mathrm{d}$ & $\mathrm{n} / \mathrm{d}$ & 1:20-25 \\
\hline Japan $^{23}$ & $10-30$ & $5-15$ & $12-19$ & $\mathrm{n} / \mathrm{d}$ & $0.7-1.25$ & $0.1-0.2$ & $\mathrm{n} / \mathrm{d}$ & $\mathrm{n} / \mathrm{d}$ & $1: 20-25$ \\
\hline Vietnam $^{24}$ & $10-18$ & $9-12$ & $16-22$ & $\mathrm{n} / \mathrm{d}$ & $\mathrm{n} / \mathrm{d}$ & $0.2-0.25$ & $\mathrm{n} / \mathrm{d}$ & $60-80$ & $1: 24-25$ \\
\hline
\end{tabular}

$\dagger$ LL: leaf length; LW: Leaf width; CV: cross veins; CVB: cross veins branching; SC: space between cross veins; SM: space between intra-marginal veins and leaf margin; SMa: space between intra-marginal veins and leaf margin at apex of leaf; AG: cross veins angle; $1 / 2 \mathrm{LW} / \mathrm{SM}$ : Half of leaf width per space between intra-marginal veins and leaf margin.

* Populations in this study from Andaman Sea, Thailand.

" Cross veins branching is common for all populations except for $H$. ovalis from Vietnam ${ }^{24}$.

${ }^{*} \mathrm{n} / \mathrm{d}=$ no data.

in $H$. major and ranged between 1:16.58-27.74 and 1:3.59-12.65 in H. ovalis without any overlapping values (Fig. $5 \mathrm{i}$ ). This, in fact, could be a dependable character for the identification of $H$. major.

\section{DISCUSSION}

H. major is reported to be distributed in Western Pacific region including Vietnam, Indonesia, Malaysia and the Indian Ocean including Thailand and Myanmar either through the morphological or molecular information ${ }^{12,19,20}$. This study was the first report, which combined both morphological features and molecular information to identify $H$. major and suggested some key characters to identify this closely similar species. Unlike the study of Nguyen et $\mathrm{al}^{20}$, where high genetic diversity of $\mathrm{H}$. ovalis was reported across the Indo-Pacific Ocean, our results showed the identical sequences of $H$. major or between Trang and Krabi provinces (haplotype Hm.1, Fig. 4), however a much smaller scale. The distance between those sites are less than $100 \mathrm{~km}$, where both influenced by the same water current thus low genetic diversity was expected. It would be interesting to further understand, dispersal, recruitment and sexual reproduction of this species.

Although $H$. major and $H$. ovalis have similar shape and shows some overlap in size among leaf age groups (Table 2), they can be clearly distinguished by (1) a significant larger leaf size in all leaf ages, especially in the age (iii) and (iv); and (2) The $1 / 2$ ratio between leaf width and the space between the intra-marginal vein and lamina margin is significantly higher in $H$. major than in $H$. ovalis. Thus we suggest that leaf ages as well as the $1 / 2$ ratio are important for distinguishing these 2 closely similar species; and as well as other Halophila spp.

Although there are significantly more cross veins in $H$. major in most mature leaves, the number of cross veins in this study ranged only 1418 , which is much lower than those reported from Japanese populations (18-22 cross veins) ${ }^{19}$. This suggested that there is high variability in this character in Halophila spp. between various populations (Table 2). Overlap of characters is common and conspecific within this group, e.g., $H$. minor and $H$. ovalis, $H$. major and H. miki, $H$. nipponica, $H$. okinawensis and $H$. gaudichaudii ${ }^{23}$. The nomenclature of the Halophila group is still confounding which limits the risk assessment of the dangers to the world's seagrass species ${ }^{29}$. In addition to the distinguishing morphological and ITS characters, sexual reproductive features, flowers and fruits, would 

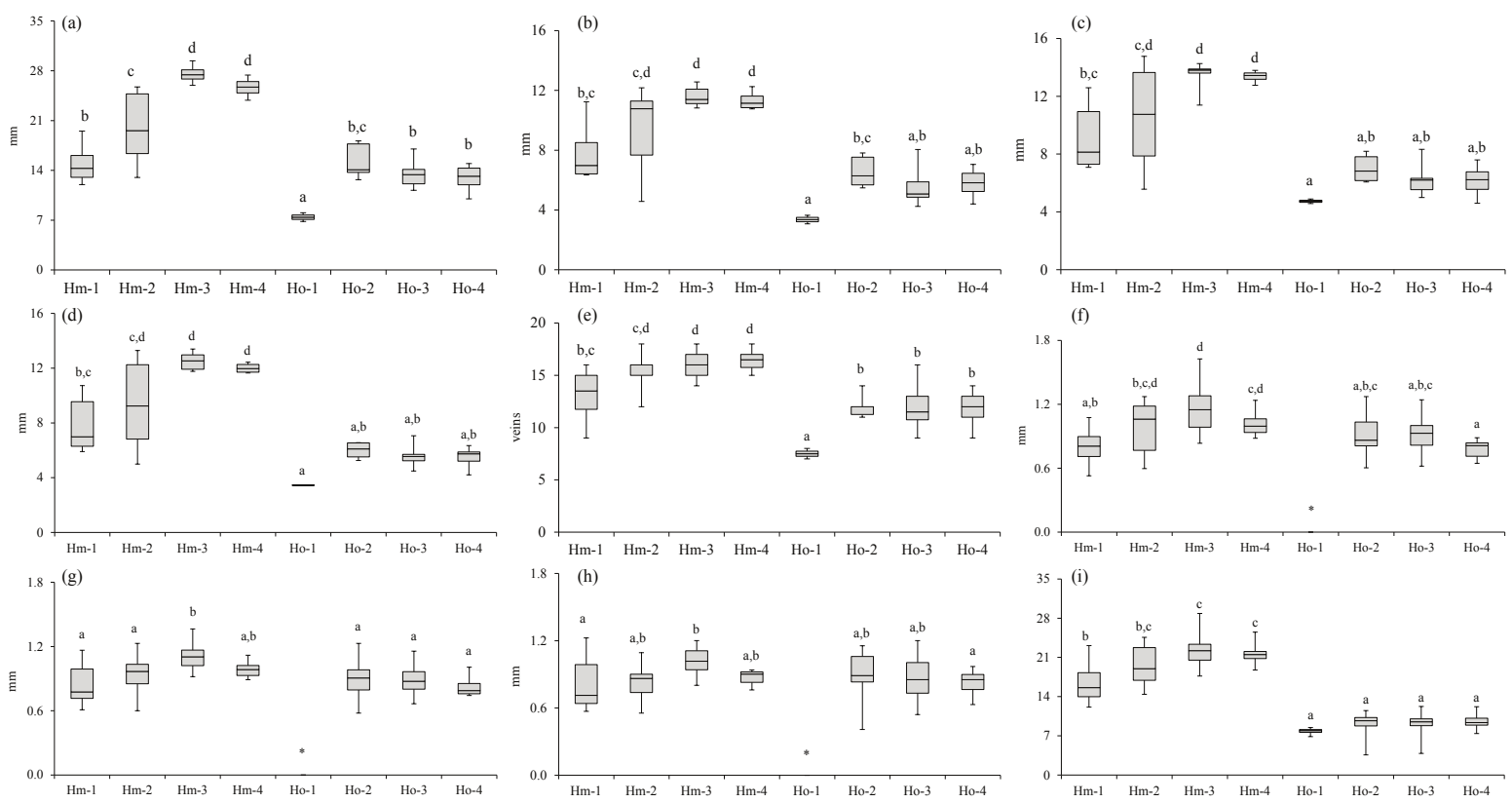

Fig. 5 Summary of morphological characters between $H$. major (Hm-) and H. ovalis (Ho-) populations among 4 age classes. Medians are highlighted in bold; bars represent the $25 \%$ and $75 \%$ quartiles; whiskers represent the lowest and highest data points. (a) Leaf length (Welch $=145.99$, $p$-value $=0.000)$; (b) leaf width at $25 \%$ leaf area $($ Welch $=90.46$, $p$-value $=0.000) ;(c)$ leaf width at the $50 \%$ leaf area $($ Welch $=183.19, p$-value $=0.000)$; $(d)$ leaf width at $75 \%$ leaf area (Welch $=597.11, p$-value $=0.000)$; $(\mathrm{e})$ number of cross veins (Welch $=44.69, p$-value $=0.000)$; (f) space between cross veins at $50 \%$ leaf area (Welch $=11.09, p$-value $=0.000)$ and $*=$ no data; $(\mathrm{g})$ space between cross at $75 \%$ leaf area $($ Welch $=12.34 ; p$-value $=0.000) ;(h)$ space between cross at $100 \%$ leaf area (Welch $=5.52, p$-value $=0.000)$ and $*=$ no data; (i) ratio between 0.5 leaf width and space between intra marginal vein and leaf edge (Welch $=77.52$, $p$-value $=0.000$ ).

complete the description of the species. Establishing those characters was outside the realm of this study.

Acknowledgements: This study was supported by Higher Education Research Promotion and National Research University Project of Thailand, Office of the Higher Education Commission (NRU). Prof. Larry B Liddle has improved the English of this manuscript. AP and SS would like to thank National Research Council of Thailand (NRCT)-Japan Society for the Promote of Science (JSPS) research collaboration scheme.

\section{REFERENCES}

1. den Hartog C (1970) Seagrasses of the World, North Holland Publishing Company, Amsterdam, The Netherlands.

2. Short F, Carruthers T, Dennison W, Waycott M (2007) Global seagrass distribution and diversity: A bioregional model. J Exp Mar Biol Ecol 350, 3-20.

3. Larkum AWD, Orth RJ, Duarte CM (2006) Seagrasses: Biology, Ecology, and Conservation, Springer, Dordrecht, The Netherlands.
4. Short FT, Moore GE, Peyton KA (2010) Halophila ovalis in the Tropical Atlantic Ocean. Aquat Bot 93, 141-6.

5. Ralph PJ, Burchett MD (1995) Photosynthetic responses of the seagrass Halophila ovalis (R. Br.) Hook. f. to high irradiance stress, using chlorophyll $a$ fluorescence. Aquat Bot 51, 55-66.

6. Ralph PJ (1998) Photosynthetic response of laboratory-cultured Halophila ovalis to thermal stress. Mar Ecol Progr 171, 123-30.

7. Shafer DJ, Sherman TD, Wyllie-Echeverria S (2007) Do desiccation tolerances control the vertical distribution of intertidal seagrasses? Aquat Bot 87, 161-6.

8. Tanaka Y, Nakaoka M (2004) Emergence stress and morphological constraints affect the species distribution and growth of subtropical intertidal seagrasses. Mar Ecol Progr 284, 117-31.

9. Kuo J, den Hartog C (2001) Seagrass taxonomy and identification key. In: Short FT, Coles RG (eds) Global Seagrass Research Methods, Elsevier Science B.V., Amsterdam, pp 31-58.

10. Chansang H, Poovachiranon S (1994) The distribution and species composition of seagrass beds along the Andaman Sea coast of Thailand. Phuket Mar Biol 
Cent Res Bull 59, 43-52.

11. Supanwanid C, Lewmanomont K (2003) The seagrasses of Thailand. In: Green EP, Short FT (eds) World Atlas of Seagrasses, UNEP World Conservation Monitoring Centre, Univ of California Press, Berkeley, USA, pp 144-51.

12. Uchimura M, Faye EJ, Shimada $\mathrm{S}$, Aral $\mathrm{S}$, Inoue $\mathrm{T}$, Nakamura Y (2008) A reassessment of Halophila species (Hydrocharitaceae) diversity with special reference to Japanese representatives. Bot Mar 51, 258-68.

13. Marsh H, Penrose H, Eros C, Hugues J (2002) Dugong: Status reports and action plans for countries and territories. UNEP Early Warning and Assessment Report Series UNEP/DEWA/RS. 02-1.

14. Hines EM, Adulyanukosol K, Duffus DA (2005) Dugong (Dugong dugon) abundance along the Andaman coast of Thailand. Mar Mamm Sci 21, 536-49.

15. Prathep A, Rattanachot E, Tuntiprapas P (2010) Seasonal variations in seagrass percentage cover and biomass at Koh Tha Rai, Nakhon Si Thammarat Province, Gulf of Thailand. Songklanakarin J Sci Tech 32, 497-504.

16. Rattanachot E, Prathep A (2011) Temporal variation in growth and reproduction of Enhalus acoroides (L.f.) Royle in a monospecific meadow in Haad Chao Mai National Park, Trang Province, Thailand. Bot Mar 54, 201-7.

17. Haynes RA (2001) Hydrocharitaceae. In: Santisuk T, Larsen K (eds) Flora of Thailand, Vol. 7, Part 3, The Forest Herbarium, Royal Forest Department, Bangkok, pp 365-82.

18. Kuo J (2000) Taxonomic notes on Halophila ovata and Halophila minor. In: Pergemp G, Pergemp-Marpini C, Buia M, Gambia M (eds) Proceedings 4th International Seagrass Biology Workshop, Biol Mar Mediterr 7, 79-82.

19. Kuo J, Kanamoto Z, Iizumi H, Mukai H (2006) Seagrasses of the genus Halophila Thouars (Hydrocharitaceae) from Japan. Acta Phytotax Geobot 57, 129-54.

20. Nguyen XV, Detcharoen M, Tuntiprapas P, Soe-Htun U, Sidik JB, Harah MZ, Prathep A, Papenbrock J (2014) Genetic species identification and population structure of Halophila (Hydrocharitaceae) from the Western Pacific to the Eastern Indian Ocean. BMC Evol Biol 14, 92.

21. Lucas C, Thangaradjou T, Papenbrock J (2012) Development of a DNA barcoding system for seagrasses: successful but not simple. PLoS ONE 7, e29987.

22. Nguyen XV, Japar SB, Papenbrock J (2013) Variability of leaf morphology and marker genes of members of the Halophila complex collected in Viet Nam. Aquat Bot 110, 6-15.

23. Uchimura M, Faye EJ, Shimada S, Aral S, Inoue T, Nakamura Y (2006) A re-evaluation of the taxonomic status of Halophila euphlebia Makino (Hydrochar- itaceae) based on morphological features and ITS sequence data. Bot Mar 49, 111-21.

24. Nguyen XV, Holzmeyer L, Papenbrock J (2013) New record of the seagrass species Halophila major (Zoll.) Miquel in Vietnam: Evidence from leaf morphology and ITS analysis. Bot Mar 56, 313-21.

25. Thompson JD, Gibson TJ, Plewniak F, Jeanmougin F, Higgins DG (1997) The CLUSTAL_X windows interface: flexible strategies for multiple sequence alignment aided by quality analysis tools. Nucleic Acids Res 25, 4876-82.

26. Posada D, Crandall KA (1998) MODELTEST: testing the model of DNA substitution. Bioinformatics 14, 817-8.

27. Stamatakis A (2006) Phylogenetic models of rate heterogeneity: a high performance computing perspective. In: Proceedings of the IPDPS2006 HiCOMB Workshop, Rhodes Island, Greece.

28. Ronquist F, Huelsenbeck JP (2003) MRBAYES 3: Bayesian phylogenetic inference under mixed models. Bioinformatics 19, 1572-4.

29. Short FT, Polidoro B, Livingstone SR, Carpenter KE, Bandeira S, Bujang JS, Calumpong HP, Carruthers $\mathrm{TJB}$, et al (2011) Extinction risk assessment of the world's seagrass species. Biol Conservat 144, 1961-71. 